\title{
DESAIN KARAKTERISTIK KAPAL MARKAS UNTUK OPERASI PE NGAMANAN PERAIRAN PERBATASAN DAN DUKUNGAN PENANGANAN PASCA BENCANA ALAM PADA MASYARAKAT PULAU TERLUAR
}

\section{CHARACTERISTICS DESIGN OF HEADQUARTERS SHIP FOR BORDER PROTECTION OPERATION AND SUPPORT TO POST- NATURAL DISASTER MANAGEMENT IN THE OUTLYING ISLANDS COMMUNITY}

\author{
Samudro a dan Abdul Kadir \\ a Pusat Teknologi Industri Pertahanan dan Keamanan BPPT \\ b Pusat Teknologi Industri dan Sistem Transportasi BPPT \\ asamudro@bppt.go.id, babdul.kadir@bppt.go.id
}

\begin{abstract}
Abstrak
Ditinjau dari segi kedaulatan dan pertahanan-keamanan nasional, keberadaan pulau-pulau terluar di perairan perbatasan di bagian utara Sulawesi Utara mempunyai arti strategis bagi Indonesia dan layak untuk diamankan. Di sisi lain, wilayah geografis Sulawesi Utara dengan beberapa gunung berapi dan perairan terbuka menghadap ke samudra Pasifik, rawan terjadi bencana alam gempa dan Tsunami. Secara konseptual strategis perlu dikaji kebutuhan sarana dukung transportasi - kapal untuk pengamanan pulau-pulau terluar dan untuk kesiagaan penanganan bencana alam bagi masyarakat wilayah perairan perbatasan. Karenanya pada kajian ini dilakukan studi disain prototip kapal markas yang dilengkapi bulbous-bow untuk mampu beroperasi sesuai karakteristik pada perairan perbatasan bergelombang tinggi, serta berfungsi sebagai sarana dukung operasional patroli pengamanan perairan perbatasan dan penanganan pasca bencana alam. Desain kapal markas panjang $66 \mathrm{~m}$ dengan daya $2 \times 155 \mathrm{HP}$, kecepatan dinas 12,5 Knot telah diuji model di laboratorium hidrodinamika untuk kemampuan ship powering, manuvering dan sea-keeping dengan hasil memenuhi ketentuan persyaratan IMO.
\end{abstract}

Kata Kunci : Desain kapal markas, pengamanan perairan perbatasan, bantuan pasca bencana alam, bulbousbow, uji laboratorium hidrodinamika

\begin{abstract}
In terms of sovereignty and defense-security national, the existence of outer islands in the border at northern North Sulawesi has strategic significance for Indonesia and is worthed to keep. On the other hand, the geographical area of North Sulawesi with several volcanoes and open waters facing the Pacific Ocean susceptible occurs earthquakes and Tsunami. In a strategic conceptual, need to be reviewed transportation support facilities such as the ship for the security of the outer islands and for the alertness of handling natural disasters for the community of border areas. Therefore, the study of a bulbous-bow headquarters ship prototype was designed adequate to operate compatible to the characteristics of high wavy border waters, as well as to support the operational patrol of border marine security and post-disaster handling. The design of the ship's $66 \mathrm{~m}$ headquarters with 2x155 HP power and the official speed of 12.5 Knot has been tested in the hydrodynamics laboratory model for ship powering, manuvering, and sea-keeping capabilities with results conform to requirements of IMO.
\end{abstract}


Keywords: Headquarters ship design, border water security, post-aid Natural disaster, Bulbousbow, hydrodynamic laboratory test

Diterima (recieved) : 15 Mei 2016, Direvisi (Revised) : 03 Oktober 2016, Disetujui

(Accepted) : 27 November 2016

\section{PENDAHULUAN}

Wilayah perairan perbatasan Indonesia yang luas berseberangan dengan 10 negara tetangga (Philipina, Malaysia, Singapura, Vietnam, Thailand, India, Australia, Timor Leste, Palau, Papua Nugini) serta memiliki kurang lebih 92 pulau-pulau terluar merupakan salah satu aspek strategis nasional. Ditinjau dari sisi kedaulatan Negara Kesatuan Republik Indonesia (NKRI), dari sisi pertahanan dan keamanan nasional, pemanfaatan sumberdaya alam serta sebagai referensi penentuan landas kontinen negara, kedudukan pulau terluar merupakan wilayah teritorial terdepan yang harus dipertahankan ${ }^{1)}$. Khususnya di wilayah perairan perbatasan bagian utara Provinsi Sulawesi Utara berbatasan dengan negara Philipina, disana terdapat pulau Marore dan pulau Miangas yang terpencil menjadi salah satu titik dasar batas wilayah Indonesia. Kondisi wilayah perairan perbatasan di bagian utara provinsi Sulawesi Utara merupakan perairan yang terbuka berhubungan langsung dengan perairan Samudera Pasifik, menjadikan titik rawan terjadi bencana badai gelombang

tinggi dan Tsunami, posisi strategis ini ditunjukkan pada Gambar 1.

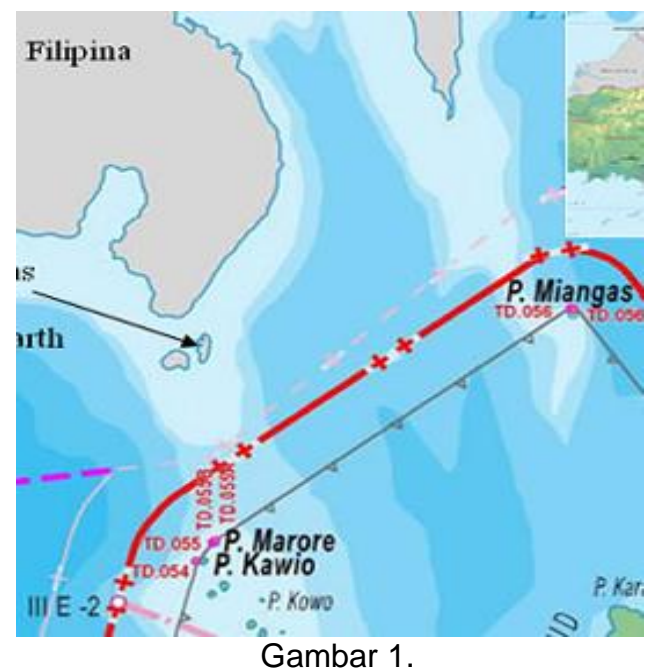

Lokasi P. Miangas dan P. Marore di Perairan Terbuka Perbatasan
Perlu dipertimbangkan pula bahwa wilayah geografi Indonesia yang dikelilingi gunung berapi aktif, menjadi wilayah pertemuan tiga lempeng besar dunia, Lempeng IndoAustralia, Lempeng Eurasia, dan Lempeng Pasifik berpotensi risiko rawan bencana gempa dan erupsi gunung berapi termasuk wilayah Sulawesi Utara terlingkup dalam rangkaian gunung berapi Indonesia. Dengan kondisi geografis seperti ini wilayah perairan perbatasan Sulawesi Utara memiliki potensi bencana alam yang cukup tinggi, antara lain gempa bumi, gunung meletus, badai tropis maupun tsunami, terutama dengan karakter serupa untuk kawasan pulau Miangas dan pulau Marore. Dengan kondisi seperti ini, penempatan pos satuan pengamanan perbatasan dan kehidupan masyarakat di wilayah pulau-pulau terluar ini juga sering mengalami kesulitan. Terlebih saat kondisi cuaca ekstrem dan bencana terjadi, dukungan transportasi logistik secara reguler untuk pos pengamanan perbatasan maupun untuk masyarakat menjadi salah satu kendala utama. Keterbatasan kapal laut pendukung suplai logistik yang mampu beroperasi pada cuaca ekstrem serta mahalnya biaya operasi kapal yang menyimpulkan pemikiran yaitu perlunya dilakukan perancangan kapal dengan karakteristik khusus untuk mendukung tugas operasional tersebut. Oleh karena itu, implementasi konseptual rancang bangun Kapal Markas sebagai pendukung operasional tugas patroli pengamanan juga berfungsi sebagai kapal pendukung logistik masyarakat dan penanganan pasca bencana alam untuk perairan perbatasan pulau-pulau terluar perlu dipertimbangkan. Kapal harus didisain sesuai karakteristik untuk beroperasi di perairan ekstrem perbatasan.

\section{Analisa Kondisi Permasalahan Kondisi perairan perbatasan}

Wilayah perairan perbatasan di bagian utara Sulawesi Utara yang menghadap ke arah Samudera Pasifik merupakan perairan terbuka seperti yang terlihat pada Gambar 1. Rata-rata pada paruh tahun terjadi perbedaan intensitas gelombang yang menyolok2). 


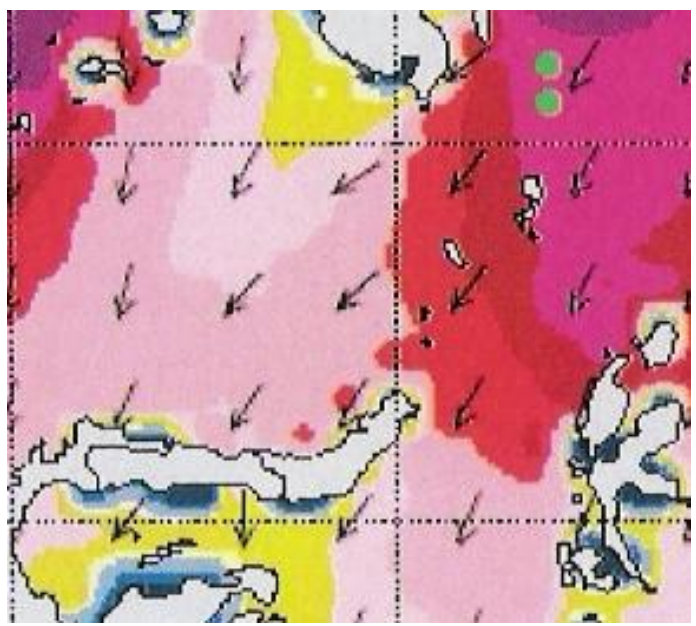

Gambar 2a.

Profil gelombang perairan utara Sulawesi Utara - bulan Januari

Pada bulan Januari-Pebruari intensitas arah gelombang dari perairan Samudra Pasifik masuk ke wilayah perairan Indonesia mengarah ke barat daya perairan SangirTalaud. Umumnya kondisi perairan relatif agak tenang, meski memungkinkan terjadi rata-rata ketinggian gelombang bisa mencapai 2 - 3 meter mendekati daerah perairan Sulawesi Utara, sementara di perairan perbatasan disekitar pulau Marore dan pulau Mianggas sampai mencapai ketinggian 4 - 5 meter, sebagaimana terlihat pada Gambar 2a. Pada bulan AgustusSeptember kondisi perairan berubah lebih ekstrim, intensitas arah gelombang mengarah ke Samudera Pasifik kearah utara-barat laut perairan Sangir-Talaud. Pada kondisi memasuki musim hujan, di perairan sekitar pulau Marore dan Miangas tinggi gelombang mancapai 5 meter lebih. Karakteristik perairan di sini cenderung ekstrim sebagaimana terlihat pada Gambar $2 \mathrm{~b}$.

\section{Bencana gunung berapi dan Tsunami di perairan perbatasan}

Wilayah geografis perairan di bagian utara Sulawesi Utara terdapat beberapa bentukan gunung berapi aktif yang berpotensi menimbulkan gempa bumi dan bencana tsunami3).

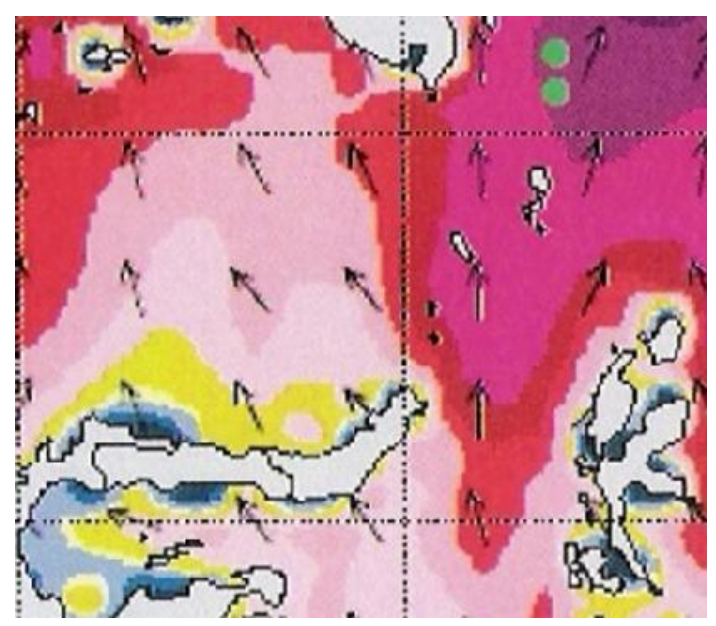

Gambar 2b.

Profil gelombang perairan utara Sulawesi

Utara - bulan Agustus

Tabel.1.

Kejadian Tsunami di Perairan Sulawesi Bagian Utara

\begin{tabular}{clcc}
\hline Tahun & \multicolumn{1}{c}{ Sumber } & Wilayah & Korban \\
\hline 1976 & $\begin{array}{l}\text { M8,1 Earth } \\
\text { quake }\end{array}$ & $\begin{array}{c}\text { SW } \\
\text { Mindanau } \\
\text { S6, Earth }\end{array}$ & 4000 \\
1918 & $\begin{array}{l}\text { M8,2 Ea } \\
\text { quake } \\
\text { Volcano, earth } \\
1871\end{array}$ & $\begin{array}{l}\text { Mindanau } \\
\text { Sulawesi } \\
\text { quake }\end{array}$ & 102 \\
1856 & Volcano & $\begin{array}{c}\text { Sea } \\
\text { Sulawesi } \\
\text { Sea }\end{array}$ & 100 \\
\hline
\end{tabular}

Beberapa data kejadian gemp abumi yang menimbulkan tsunami seperti pada Tabel 1 . Dari hasil beberapa prediksi simulasi terjadinya gempa bumi akibat tubrukan ataupun interseksi antar lempeng bumi maupun pertumbuhan gunung berapi di wilayah perairan bagian Utara Sulawesi Utara tercatat bahwa potensi sumber gempa akan terjadi di daerah perairan dangkal kedalaman < $6000 \mathrm{~m}$ namum dapat menimbulkan besaran gempa bumi sampai M 7,8. Hal ini dapat menimbulkan ketinggian ombak sampai dengan $4 \mathrm{~m}$. Demikian juga dari hasil prediksi simulasi Tsunami yang terjadi di daerah garis pantai pulau pulau di bagian utara Sulawesi Utara ketinggian permukaan perairan dapat mencapai ketinggian melebihi $10 \mathrm{~m}^{3}$ ). 


\section{Karakteristik Desain Kapal Markas untuk perairan perbatasan}

Kapal Markas dirancang sesuai dengan karakteristik kondisi operasional kapal di perairan perbatasan utara Sulawesi Utara. Kapal mampu beroperasi pada kondisi tinggi gelombang ekstrem dengan kemampuan olah gerak (ship maneuvring) dan kehandalan (sea -keeping quality performance) yang memenuhi persyaratan IMO. Untuk mendukung efektifitas kemampuan daya gerak kapal diperairan bergelombang, di bagian haluan kapal dipasang bulbous bow untuk membantu pengurangan hambatan gelombang pada kapal.

Kapasitas kapal dirancang mampu memuat keperluan transportasi satuan pengamanan dan perlengkapan satuan serta dukungan logistik perlengkapan operasi untuk penanganan bantuan pasca bencana di wilayah pulau terluar. Kecepatan dan jarak jelajah kapal dirancang cukup mampu beroperasi dari pangkalan TNI-AL di kota Bitung untuk mencapai jangkauan jarak jelajah penanganan lokasi darurat terjauh dalam waktu tidak lebih dari 3 hari.

Dalam perancangan Kapal Markas, kapal mempunyai 3 misi dasar/ peran utama, yaitu : (1) Kapal berperan sebagai kapal pendukung patroli reguler dalam wilayah perairan perbatasan, (2) Kapal menjadi sarana transportasi satuan pengamanan dan bantuan pengiriman logistik di wilayah pulau terluar perairan perbatasan, (3) Kapal menjadi sarana transportasi bantu untuk penanganan pasca bencana alam pada masyarakat dengan peran sebagai poliklinik darurat terapung pada satu wilayah pulau terluar perbatasan ${ }^{4}$.

\section{BAHAN DAN METODE}

Metodologi perancangan Kapal Markas untuk patroli pengamanan, transportasi rotasi pasukan penjagaan dan dukungan penanganan pasca bencana pada daerah perairan Utara Sulawesi melalui tahapan :

\section{TAHAP (1)}

- Kajian misi azasi fungsi dan kebutuhan kapal markas multi guna

- Kajian batasan / konstrain faktor geaografis daerah operasi kapal, kondisi perairan serta faktor geopolitis daerah perbatasan antar negara.

- Kajian khusus kondisi operasional perairan (Ombak, Arus laut)
TAHAP (2)

- Perancangan Konsep Kapal Markas dilanjutkan dengan kajian syarat Operational requirement (Opsreq) dan penyusunaan spsifikasi teknis kapal Markas (Spektek)

- Kajian pada pradesain kapal melalui perhitungan numerik

- Kajian hasil pengujian hidrodinamika model kapal pada kolam uji (ship powering) dan pengujian numerik kemampuan olah gerak dan kehandalan kapal (ship maneuvring, sea-keeping)

TAHAP (3)

- Kajian kemampuan teknis kapal Markas serta membandingkan dengan kondisi perairan

- Hasil akhir rekomendasi karakteristik desain kapal yang memenuhi syarat

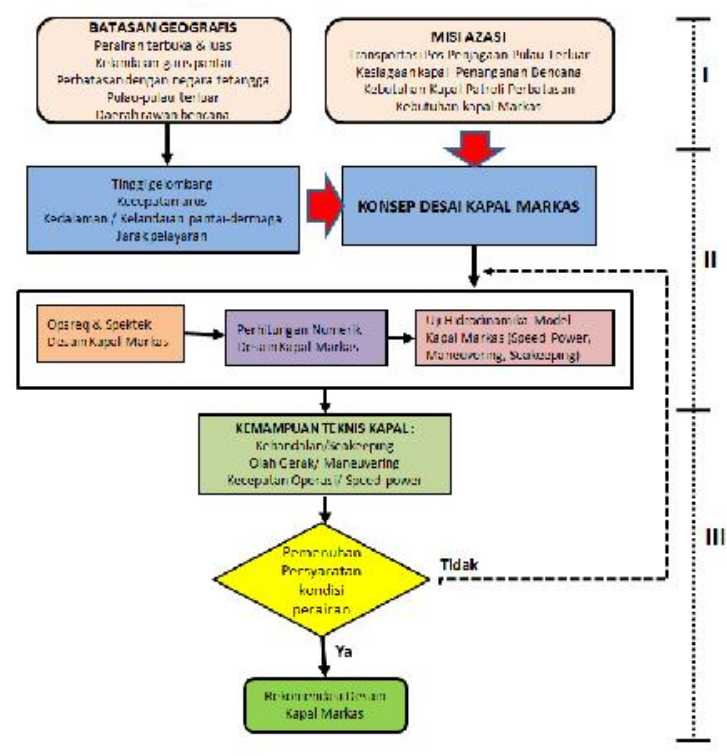

Gambar 3.

Diagram Metodologi

\section{HASIL DAN PEMB AHASAN}

\section{Rancangan Kapal Markas Optimasi lambung haluan dan Tenaga penggerak kapal}

Rancangan dasar Kapal Markas untuk mendukung patroli pertahanan dan keamanan pulau terluar perairan perbatasan serta untuk bantuan penanganan pasca bencana alam pada masyarakat pulau terluar ditampilkan pada Gambar 4a Lines plan lambung kapal dan $4 \mathrm{~b}$ General 
arrangement Kapal Markas serta Ukuran

Utama kapal ditampilkan pada Tabel 2.

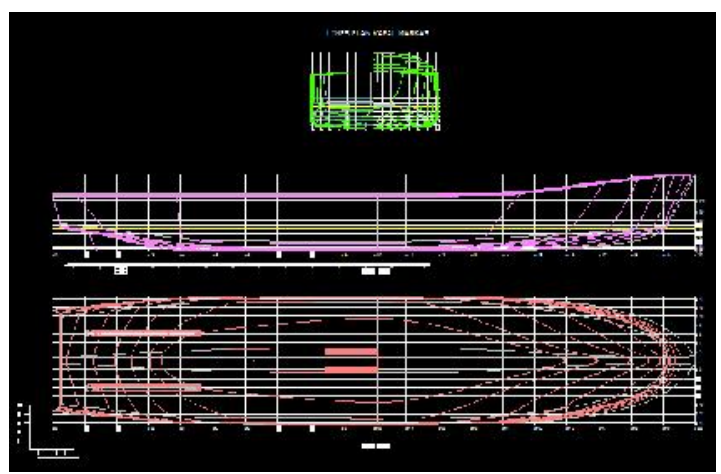

Gambar 4a.

Lines Plan Kapal Markas

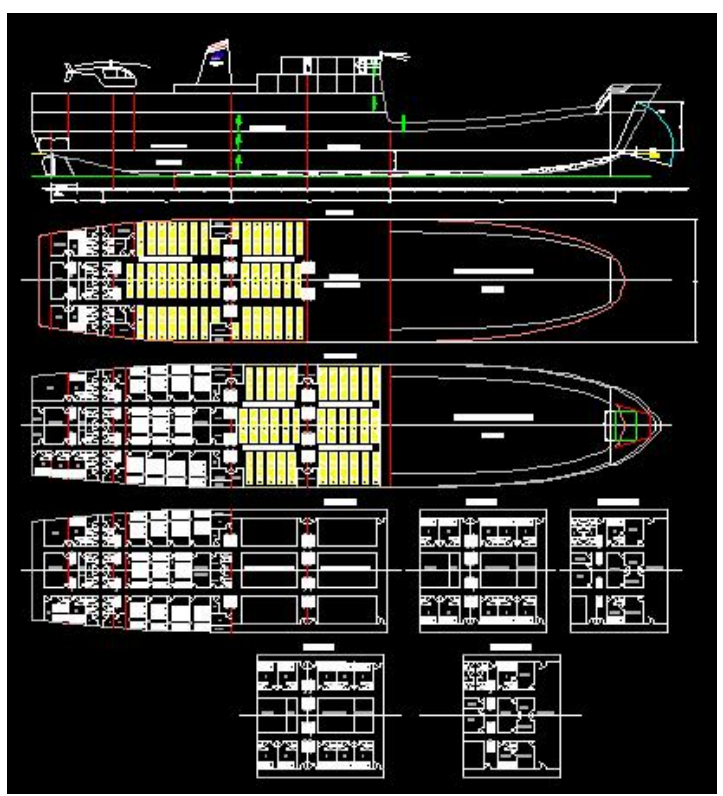

Gambar 4b.

General Arrangement Kapal Markas.

Dalam rancangan dasar lambung kapal diasumsikan kapal beroperasi di wilayah perairan tenang, sehingga bentuk haluan tidak dilengkapi bulbousbow. Selain itu, kapal dirancang dengan sarat air rendah dan lunas datar serta dilengkapi dengan pintu ram-door. Hal ini untuk memudahkan kapal beroperasi di wilayah perairan dangkal serta mudah merapat di pantai pasir (beaching).
Tabel 2.

Ukuran Utama Kapal Markas

\begin{tabular}{|c|c|c|c|}
\hline Notasi & Ukuran Utama & Nilai & Satuan \\
\hline LOA & $\begin{array}{l}\text { Panjang total } \\
\text { kapal }\end{array}$ & 73,66 & $\mathrm{~m}$ \\
\hline LWL & Panjang garis air & 67,45 & $\mathrm{~m}$ \\
\hline LPP & $\begin{array}{c}\text { Panjang batas } \\
\text { kapal }\end{array}$ & 66,76 & $\mathrm{~m}$ \\
\hline B & Lebar kapal & 14,46 & $\mathrm{~m}$ \\
\hline $\mathrm{H}$ & Tinggi geladak & 8,45 & $\mathrm{~m}$ \\
\hline $\mathrm{T}$ & Sarat air & 2,50 & $\mathrm{~m}$ \\
\hline $\mathrm{Cb}$ & Koef. Bentuk & 0,699 & \\
\hline $\mathrm{Cp}$ & Koef. Prismatik & 0,753 & \\
\hline $\mathrm{Cm}$ & $\begin{array}{l}\text { Koef. Midship/ } \\
\text { tengah }\end{array}$ & 0,928 & \\
\hline Disp & $\begin{array}{c}\text { Volume /bobot } \\
\text { kapal }\end{array}$ & 1648 & Ton \\
\hline $\mathrm{P}$ & $\begin{array}{c}\text { Tenaga } \\
\text { penggerak }\end{array}$ & $\begin{array}{c}2 x \\
1500\end{array}$ & HP \\
\hline $\mathrm{Vd}$ & Kecepatan dinas & 12,5 & Knot \\
\hline
\end{tabular}

Lambung utama kapal dibuat dari material baja serta dikombinasikan dengan alumunium untuk bangunan atas. Hal ini untuk lebih memperingan struktur badan kapal namun tetap mempertahankan posisi titik berat kapal rendah untuk meningkatkan performansi stabilitas kapal. Bangunan atas kapal dirancang berkapasitas cukup untuk akomodasi dan pengangkutan peralatan bantu satuan pengamanan maupun dukungan penanganan bantuan pasca bencana alam. Geladak bangunan atas difungsikan sebagai ruang akomodasi 15 awak kapal, 200 orang untuk rotasi satuan pengamanan, yang juga dapat difungsikan untuk ruang rawat 30 paramedis/relawan serta disediakan 100 tempat tidur darurat untuk pasien (pelayanan darurat kesehatan pasca bencana $)^{5}$. Sistem tenaga penggerak kapal dirancang mampu menggerakan kapal beroperasi dengan kecepatan dinas 12,5 Knot. Dengan menggunakan metode perhitungan hambatan kapal secara statistik yang dikembangkan oleh Holtrop dan J.Mennem ${ }^{6}$, dengan persamaan :

$$
R T=1 / 2 . \rho . V^{2} \text {. S. CT (Kg) }
$$

dimana : RT = tahanan total kapal $(\mathrm{Kg}) ; \mathrm{CT}=$ koefisien tahanan total; $\rho f=$ massa jenis fluida $\left(\mathrm{kg} / \mathrm{m}^{2}\right) ; \mathrm{V}=$ kecepatan $\mathrm{kapal}(\mathrm{m} / \mathrm{s}) \mathrm{S}=$ luas lambung basah kapal $\left(\mathrm{m}^{2}\right)$ 
Dapat dihitung daya efektif total mesin penggerak kapal, diperoleh sebesar $2 \times 1500$ HP. Kondisi daerah operasional kapal di wilayah perairan perbatasan cukup ekstrem dengan sekala sea-state $3 \mathrm{~s} / \mathrm{d} 5$, maka untuk ekektifitas daya dorong sistem propulsi kapal guna mempertahankan kecepatan dinas rata-rata 12,5 knot, perlu ditambahkan pada haluan kapal bentuk bulbous bow yang optimum.

\section{Disain Bulbous-bow Kapal}

Penggunaan bentuk bulbous-bow yang optimum pada haluan kapal dapat mengurangi besar hambatan kapal karena efek gelombang. Sehingga secara langsung akan mengoptimalkan kinerja sistem propulsi kapal, yang pada akhirnya akan terkait erat dengan peningkatan efisiensi beaya bahan bakar pengoperasian kapal. Penggunaan CFD pada analisa rancangan bentuk bulbousbow membantu evaluasi 3 tipe bulbous-bow yang paling optimal dalam mereduksi tahanan kapal, sebagaimana pada Gambar 5a, 5b, 5c dan 5d. Pada gambar tersebut ditampilkan degradasi warna, pola aliran dan distribusi tekanan fluida hidrodinamik pada bagian haluan kapal pada kecepatan dinas 12,5 knot ${ }^{7)}$. Pada Gambar 5a. ditampilkan pola aliran dan distribusi tekanan fluida pada bentuk haluan kapal tanpa dilengkapi dengan bulbous-bow

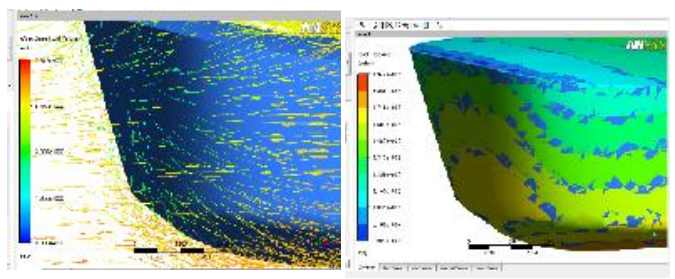

Gambar.5a.

Pola Aliran dan Distribusi Tekanan Fluida Kapal Non Bulbous-Bow

Pada Gambar 5b. ditampilkan pola aliran dan distribusi tekanan pada Bulbous-bow Tipe (1) pada bagian haluan model kapal.

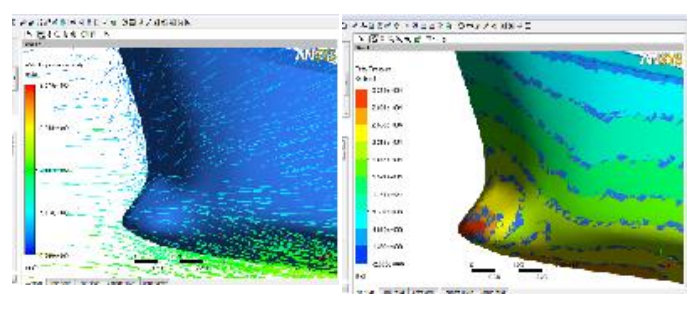

Gambar.5b.
Pola aliran dan distribusi tekanan fluida Bulbous-bow Tipe (1)

Pada Gambar 5c. ditampilkan pola aliran dan distribusi tekanan fluida pada bentuk Bulbousbow Tipe (2) pada haluan kapal.

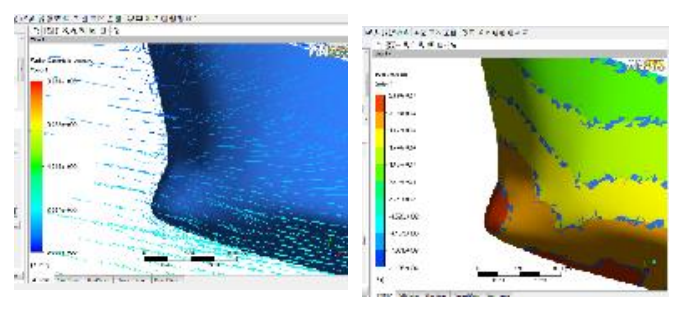

Gambar.5c.

Pola aliran dan distribusi tekanan fluida Bulbous-bow Tipe (2)

Pada Gambar 5d. ditampilkan pola aliran dan distribusi tekanan pada Bulbous-bow Tipe (3) pada bagian haluan model kapal. Dari observasi bentuk dan pola aliran serta distri busi tekanan pada bulbous kapal dapat dianalisa perbandingan tahanan gelombang yang terjadi di kapal.

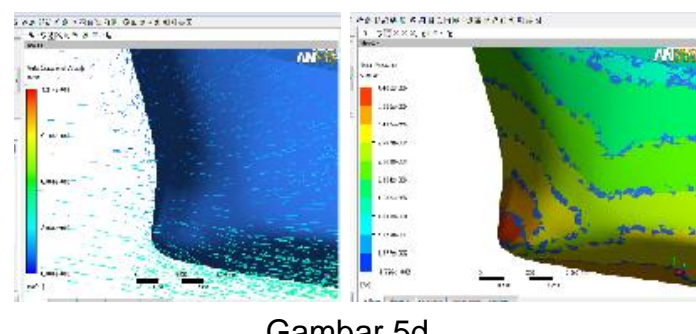

Pola aliran dan Distribusi Tekanan Fluida Bulbous-Bow Tipe (3)

Tabel 3.

Perbandingan Hambatan Kapal

\begin{tabular}{ccccc}
\hline $\begin{array}{c}\text { Kec. } \\
\text { (Knot) }\end{array}$ & $\begin{array}{c}\text { Hambatan Kapal Markas (kN) } \\
\text { Tanpa } \\
\text { BB }\end{array}$ & $\begin{array}{c}\text { BB } \\
\text { Tipe 1 }\end{array}$ & $\begin{array}{c}\text { BB } \\
\text { Tipe 2 }\end{array}$ & $\begin{array}{c}\text { BB } \\
\text { Tipe 3 }\end{array}$ \\
\hline 12.5 & 82.315 & 77.390 & 71.899 & 80.821 \\
$\begin{array}{c}\% \\
\text { Reduksi }\end{array}$ & 0 & 5,98 & 12,65 & 1,81 \\
\hline
\end{tabular}

Pada Tabel 3 ditampilkan hasil evaluasi simulasi numerik CFD pada ke 3 bentuk tipe bulbous-bow yang dipasang pada haluan Kapal Markas. Tampak bahwa perbedaan besaran tahanan kapal antar variasi bentuk desain bulbous-bow kapal dipengaruhi oleh 
Desain Karakteristik Kapal Markas untuk Operasi Pengamanan Perairan Perbatasan dan Dukungan Penanganan Pasca Bencana Alam pada Masyarakat Pulau Terluar (Samudro, Abdul Kadir)

pola aliran dan kerapatan distribusi tekanan fluida haluan kapal. Dari ke 3 tipe bulbousbow yang dianalisa terlihat bentuk Bulbousbow Tipe (2) yang paling optimal dalam reduksi hambatan total kapal, yakni sebesar $12,65 \%$ dibanding bentuk tipe bulbous-bow yang lain.

\section{Kemampuan Olah Gerak Kapal}

Kemampuan kapal untuk dapat berolah gerak dan sandar di dermaga terbatas pulau kecil, maka kemampuan Turning circle sangat diperlukan7). Kemamapuan kapal telah diuji pada Lab. Hidrodinamika. Kapal pada kondisi full load dengan kecepatan dinas 12 knot diuji membelok ke kanan (starboard) pada sudut kemudi $35^{\circ}$ dan membelok ke kiri (portside) pada sudut kemudi yang sama ${ }^{8)}$. Hasil pengujian tersebut menunjukan bahwa kemampuan olah gerak kapal cukup memenuhi persyaratan $\mathrm{IMO}^{(9)}$. Grafik hasil uji olah gerak kapal ditampilkan pada Gambar 6a dan $6 b$.

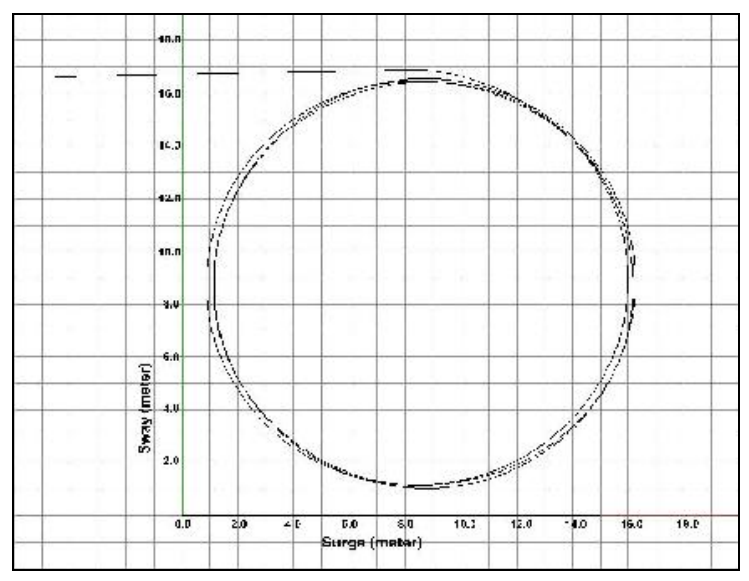

Gambar 6a.

Model Lintasan Turning Circle SB, Vd $=12$, knot, $\alpha=35^{0}$

Pada kondisi pengujian gerak memutar kapal ke kanan (starboard), rata-rata radius putar kapal relatif sama, diameter taktis (Tactical diameter) mencapai 161,56 m dengan ratarata waktu tempuh melingkar $T_{360}=198$ detik.

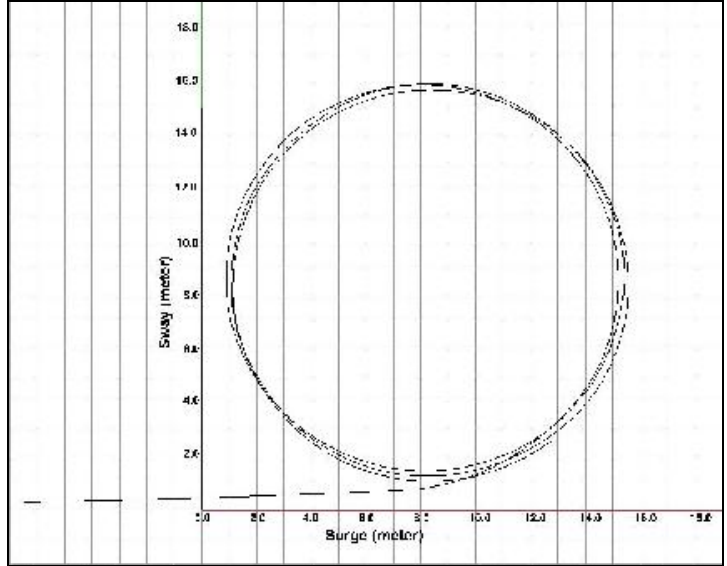

Gambar 6b.

Model lintasan Turning circle PS, $\mathrm{Vd}=12$, knot, $\alpha=35^{0}$

Pada kondisi pengujian gerak memutar kapal ke kiri (portside), diameter taktis (Tactical diameter) mencapai 160,89 m dengan ratarata waktu tempuh melingkar $\mathrm{T}_{360}=197$ detik.

Tabel 4.

Hasil Pengujian Turning Circle

\begin{tabular}{lcc}
\hline \multirow{2}{*}{\multicolumn{1}{c}{ PARAME TE R }} & \multicolumn{2}{c}{ R udder Angle } \\
\cline { 2 - 3 } & $\mathbf{3 5}^{0} \mathbf{P S}$ & $\mathbf{- 3 5}{ }^{0} \mathbf{S B}$ \\
\hline Advance $(\mathrm{m})$ & 197,61 & 199,61 \\
Transverse $(\mathrm{m})$ & 60,08 & 60,75 \\
Tactical diameter $(\mathrm{m})$ & 160,89 & 161,56 \\
Turning diameter $(\mathrm{m})$ & 122,17 & 122,17 \\
& & \\
Advance/Lpp & 2,96 & 2,99 \\
Transverse/Lpp & 0,90 & 0,91 \\
Tactical diameter/Lpp & 2,41 & 2,42 \\
Turning diameter/Lpp & 1,83 & 1,83 \\
\hline
\end{tabular}

Keseluruhan hasil pengujian simulasi Turning circle kapal ditampilkan pada Tabel 5. Terlihat bahwa pada parameter rasio didapat Advance/Lpp $=2,96 \& 2,99$ dan rasio Tactical/Lpp $=2,41 \quad \& \quad 2,42$ kedua hasil tersebut telah memenuhi kriteria standar olah gerak (maneuver) yang disyaratkan oleh IMO9).

\section{Kemampuan Seakeeping kapal}

Untuk mengetahui pola karakteristik performansi Kapal dan kinerja stabilitas dinamis kapal diatas gelombang laut pada kecepatan dinas serta untuk menganalisa kemungkinan masuknya air laut (deck 
wetness) dari bagian bukaan (opening) diatas free deck (deck utama), maka perlu dilakukan pengujian seakeeping. Simulasi pengujian ini menggunakan perangkat lunak Ship motion dynamic. Dalam pengujian disini dianalisa parameter gerakan kapal yang siknifikan dan paling dominan, yakni gerakan rolling, pitching dan heaving serta gerakan ekstrim kapal yang menyebabkan kondisi deck wetness.

Tabel 5.

Karakteristik Gelombang untuk Uji Seakeeping

\begin{tabular}{|c|c|c|c|c|}
\hline \multicolumn{2}{|c|}{$\begin{array}{c}\text { Tinggi } \\
\text { Gelombang }\end{array}$} & \multirow[t]{2}{*}{$\begin{array}{l}\text { Period } \\
\text { [m] }\end{array}$} & \multirow[t]{2}{*}{$\begin{array}{l}\text { Arah } \\
\text { [deg] }\end{array}$} & \multirow[t]{2}{*}{ Note } \\
\hline $\begin{array}{c}\text { Siknif } \\
\text { [m] }\end{array}$ & $\begin{array}{c}\text { Maks } \\
{[\mathrm{m}]}\end{array}$ & & & \\
\hline 1,27 & 2,36 & 5,63 & $\begin{array}{c}90,135 \\
180\end{array}$ & $\begin{array}{l}\text { Moderat } \\
\text { e Seas }\end{array}$ \\
\hline 2,80 & 5,20 & 8,64 & $\begin{array}{c}90,135 \\
180\end{array}$ & $\begin{array}{c}\text { Extrem } \\
e \\
\text { Seas }\end{array}$ \\
\hline
\end{tabular}

Karakteristik tinggi gelombang yang digunakan dalam pengujian adalah kondisi gelombang sea-state 3 dan 5 sebagaimana pada Tabel 5. Sedangkan spektrum gelombang yang digunakan adalah tipe Pierson-Moskowitz (P-M) (10), yang diformulasikan sebagai berikut :

$$
S_{\varsigma}(\omega)=A \cdot \omega^{-5} \cdot e^{-B \cdot \omega^{-4}}
$$

dimana : $S_{\zeta}(\omega)=$ spectral density of wave heights; $\omega=$ circular frequency $(\mathrm{rad} / \mathrm{sec}) ; \mathrm{A}=$ $172.8^{*}\left(\zeta_{w 1 / 3}\right)^{2 *}(T)^{-4} ; B=691{ }^{*}(T)^{-4}$;

$\zeta_{\mathrm{w} 1 / 3}=$ significant wave height (meter);

$\mathrm{T}=$ average wave period (second)

Hasil analisa simulasi numerik pengujian berupa response amplitude operators (RAOs) yaitu rasio amplitude gelombang (wave amplitude) terhadap amplitude masing-masing gerakan (motion amplitude) kapal (Rolling, Piching dan Heaving) pada setiap frekuensi gelombang untuk kondisi sea-state 3 dan 5. Respon tersebut dirumuskan sebagai berikut :

$$
H_{u}=\frac{u_{a}\left(\omega_{e}\right)}{\zeta_{a}\left(\omega_{e}\right)}=\sqrt{\frac{S_{u u}\left(\omega_{e}\right)}{S_{\zeta \zeta}\left(\omega_{e}\right)}}
$$

dimana : $\mathrm{H}_{\mathrm{u}}=$ response function of a signal $\mathrm{u} ; \mathrm{U}_{\mathrm{a}}\left(\omega_{\mathrm{e}}\right)$ = amplitude of frequency (3) )f signal $u ; \zeta_{\mathrm{a}}\left(\omega_{\mathrm{e}}\right)=$ amplitude of frequency $\omega_{\mathrm{e}}$ of wave elevation $\zeta$; $S_{u u}\left(\omega_{e}\right)=$ spectral density of signal $u ; S_{\zeta \zeta}\left(\omega_{e}\right)=$ spectral density of wave elevation $\zeta$

Tampilan respon RAO berupa grafik, ditampilkan pada data terlampir. Dari hasil evaluasi pengujian simulasi sea-keeping dapat diresumekan kondisi gerakan kapal (Rolling, Piching dan Heaving) sebagai berikut :

- Gerakan rotasi oleng Roll Motion : Gerakan oleng dapat menimbulkan sudut dinamis yang besar diakibatkan energi atau gaya gelombang bahkan akan menimbulkan eksitasi rolling motion yang ekstrim pada kondisi frekuensi resonansi. Tampak bahwa pengaruh arah gelombang terhadap respon kapal cukup signifikan, yakni kondisi arah gelombang $90^{\circ}$ (beam seas) pada sea-state 5 , maksimum significant amplitude "roll motion" yang terjadi pada kapal sebesar 10.3 derajat (atau rms 5.02 derajat). Sedangkan respon kapal pada arah gelombang $135^{\circ}$ (bow quartering seas ) dan $180^{\circ}$ (head seas) adalah sangat kecil yaitu 0.00- 2.22 derajat (atau rms 0.00- 1.11 derajat) jika dibandingkan standar "Seakeeping Performance Criteria" 1 ) adalah rms (root mean square) max.: 9.6 derajat.

- Gerakan rotasi angguk Pitch Motion : Gerakan tersebut sangat dominan terjadi anggukan naik dan turunnya haluan maupun buritan kapal. Gerakan tersebut sangat tergantung pada kondisi gelombang, kecepatan kapal dan arah kapal terhadap gelombang. Hasil perhitungan memperlihatkan bahwa maximum significant amplitude "pitch motion" terjadi pada kondisi gelombang Sea-state 5 untuk arah gelombang $135^{\circ}$ (bow quartering seas ) yakni sebesar 2.34 derajat (atau rms 1.17 derajat). Sedangkan respon kapal pada arah gelombang $180^{\circ}$ (head seas ) dan $90^{\circ}$ (beam seas ) adalah relative lebih kecil yaitu 1.78 dan 1.93 derajat (atau rms 0.89 dan 0.96 derajat). Adapun standar "Seakeeping Performance

1) Principles of Naval Architecture:

"Seakeeping Performance Criteria". 
Criteria adalah rms (root mean square) max.: 1.5 derajat.

- Gerakan translasi vertikal Heave Motion: Gerakan vertikal naik dan turunnya badan kapal yang berkaitan erat dengan pitch motion. Maksimum Significant amplitude "heave motion" yang terjadi pada kapal yakni kondisi arah gelombang $90^{\circ}$ (beam seas) pada sea-state 5 , dimana maksimum significant amplitude yang terjadi pada kapal sebesar $1.32 \mathrm{~m}$ (atau rms $0.66 \mathrm{~m}$ ). Sedangkan respon kapal pada arah gelombang $135^{\circ}$ (bow quartering seas ) adalah $1.206 \mathrm{~m}$ (atau rms $0.603 \mathrm{~m}$ ), dan respon kapal pada arah gelombang $180^{\circ}$ (head seas) lebih kecil yakni $0.872 \mathrm{~m}$ (atau rms $0.436 \mathrm{~m}$ ).

\section{Kemampuan deck-weetnes}

Deck weetnes, masuknya air di atas geladak (deck) dari bukaan (opening) akibat eksitasi gelombang yang menyebabkan gerakan ekstrim kapal. Dari hasil perhitungan gerakan ekstrim kapal: deck wetness pada kondisi gelombang seastate 3 dan 5 , terjadi kelimpahan/ masuknya air pada geladak (deck) bila level air melewati freeboard efektif kapal atau bukaan pada lambung kapal. Pada desain Kapal Markas memiliki bukaan pada lambung (starboard - portside) kapal dengan ukuran tinggi $1.2 \mathrm{~m}$, dengan jarak ketinggian bukaan dari garis dasar (baseline) / keel 9.1 meter, seperti pada Gambar 7. Hal ini menyebabkan kemungkinan air laut masuk dari bukaan pada lambung kapal bila kapal mengalami sudut oleng (rolling) lebih besar dari $22^{\circ}$ (Gambar 7). Dari hasil perhitungan gerakan seakeeping kapal, khususnya saat gerakan rolling pada kondisi gelombang paling ekstrim (seastate-5) dan arah gelombang $90^{\circ}$ (beam seas) hanya oleng sebesar $10^{\circ}$. Sedangkan sudut oleng yang memungkinkan air dapat masuk melalui bukaan (opening) tersebut adalah oleng 22 o, berarti kemungkinan air masuk melalui bukaan (opening) tidak terjadi. Hasil perhitungan terjadinya deck wetness disajikan dalam nilai probabilitas, $\mathrm{Hal}$ ini memperlihatkan bahwa terjadinya deck wetness pada kapal adalah $0 \%$ pada kondisi gerakan ekstrem kapa.

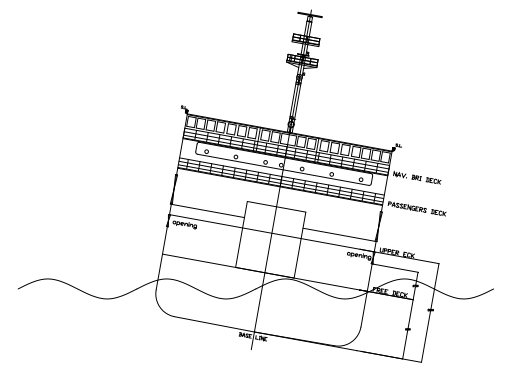

Gambar 7.

Model Gerakan Ekstrem Kapal Dan

Kelimpahan Geladak (Deckweetnes)

\section{SIMPULAN}

Dari hasil penelitian dapat disimpulkan bahwa rancang bangun kapal markas sangat diperlukan guna difungsikan sebagai sarana transport dukungan pengamanan pulaupulau terluar demi kedaulatan NKRI, melalui angkutan rotasi petugas keamanan/ TNI. Oleh karena itu, pengoperasian Kapal Markas bersinergi untuk mendukung operasi bantuan pasca bencana alam bagi masyarakat kepulauan terluar melalui angkutan distribusi logistik, penyediaan sarana poliklinik darurat terapung maupun.sebagai markas komando operasional darurat. Salah satunya dengan membuat kapal markas yang dirancang mampu beroeprasi sesui karakteristik wilayah perairan terluar pada kondisi ekstrim hingga seastate 5 dimana unjuk kerja desain Kapal Markas telah teruji di Laboratorium Hidrodinamika dan memenuhi kriteria yang disyaratkan oleh IMO

\section{UCAPAN TERIMA KASIH}

Kami mengucapkan terima kasih kepada Kemenristek Dikti yang memberikan program riset insentif Kemenristek TA 2010 - 2011 serta Dislitbang TNI AL, Pusat Penanganan Bencana, dan Kementerian Kesehatan yang berperan sebagai narasumber. Selain itu, kami mengucapkan terima kasih kepada BPPH BPPT - Surabaya untuk uji hidrodinamika model kapal di lakukan di kolam Towing Tank. 


\section{DAFTAR PUSTAKA}

1. Nazarudin, "Model penanganan pulau terluar berdasarkan konsep Prosperity dan Security Approach oleh TNl", Jurnal Litbang Pertahanan Indonesia - Balitbang Kemhan, Vol. 15, No. 2, 2012

2. Peta data arah dan ketinggian Gelombang Perairan Indonesia, BMKG, 2009

3. Lovholt, F., Khun, D., Bungum H., Harbitz C.B., dan Glimsdal,S., "Historical Tsunamis and Present Tsunami Hazard in Eastern Indonsia and the South Philippines", Journal of Geophysical Research, Vol. 117, B09310, doi:10.1029/2012JB009425, 2012.

4. Samudro, Abdul Kadir, "Rancangan Konseptual Ganda Kapal Markas Untuk Pengamanan Pulau Pulau Terluar Perairan Perbatasan NKRI (Tinjauan untuk wilayah perairan pulau Marore dan Miangas)", Jurnal Warta Penelitian Perhubungan, Balitbang Kementerian Perhubungan, Vol. 26, No. 1. 2014.
5. Kadir, A., Samudro, Waluyo,. Priatno, D.H, Akhirudin, M., Laporan Riset Rancang Bangun Kapal Markas, Pusat Teknologi Industri dan Sistem Transportasi, BPPT, 2011.

6. Harvald, Sv.Aa, Tahanan dan Propulsi Kapal, Airlangga University Press, Surabaya, 1992.

7. Jamaluddin A.dan Samudro, Analisa dan Evakuasi Faktor Faktor yang Mempengaruhi Karakteristik Olah Gerak (Maneuver) Kapal, Jurnal Perhubungan Vol. No. , 2010.

8. Laboratorium Hidrodinamika Indonesia, Laporan Hasil Pengujian Turning Cicle dan Sea-keeping Model Kapal Markas, UPT BPPH - BPPT, 2011.

9. International Maritime Organization (IMO), "Manoeuvrability of Ships and Manouevring Standards", Sub Committee on Ship Design and Equipment 36th session, Agenda item 4, 24 February 1993.

10. Pierson, W.J. dan Moskowitz, L. , "A proposed spectral form for fully developed wind seas based on similarity theory of S.A. Kitaigorodskii", 